\title{
PENGARUH MODEL PEMBELAJARAN AUDITORY, INTELLECTUALY, REPETITION BERBANTUAN MEDIA AUDIO VISUAL TERHADAP KOMPETENSI PENGETAHUAN IPA
}

\author{
Kd Ayu Yunita Kawi ${ }^{1}$, I Ngh Suadnyana ${ }^{1}$, IB Surya Manuaba ${ }^{2}$ \\ 1,2,3 Jurusan Pendidikan Guru Sekolah Dasar, FIP \\ Universitas Pendidikan Ganesha \\ Singaraja, Indonesia \\ e-mail: kd.ayu.yunita.kawi@undiksha.ac.id ${ }^{1}$, inengah.suadnyana@undiksha.ac.id ${ }^{1}$, \\ idabagussurya.manuaba@undiksha.ac.id ${ }^{2}$
}

\begin{abstract}
Abstrak
Penelitian ini bertujuan untuk mengetahui perbedaan yang signifikan kompetensi pengetahuan IPA antara kelompok siswa yang dibelajarkan melalui model pembelajaran auditory, intellectualy, repetition berbantuan media audio visual dengan kelompok siswa yang dibelajarkan melalui pembelajaran konvensional di kelas IV SD Gugus Kompyang Sujana Kecamatan Denpasar Utara tahun ajaran 2017/2018. Jenis penelitian ini eksperimen kuasi menggunakan desain rancangan kelompok non-ekuivalen. Populasi penelitian meliputi seluruh siswa kelas IV SD Gugus Kompyang Sujana Kecamatan Denpasar Utara tahun ajaran 2017/2018 sebanyak 346 siswa. Sampel ditentukan dengan teknik sampel kelompok, yaitu melakukan random pada kelompok kelas, sehingga diperoleh kelas IVA SD Negeri 4 Tonja sebagai kelas eksperimen dan kelas IV SD Negeri 4 Peguyangan sebagai kelas kontrol Hasil perhitungan data gain skor ternormalisasi kompetensi pengetahuan IPA menunjukan nilai rata-rata kompetensi pengetahuan IPA siswa kelas eksperimen lebih tinggi dari ratarata kompetensi pengetahuan IPA siswa kelas kontrol ( $\overline{\mathrm{x}}$ eksperimen $=0,63>\overline{\mathrm{x}}$ kontrol $=0,50$ ). Pengujian hipotesis dianalisis menggunakan uji-t rumus dengan polled varians. Kriteria pengujian pada taraf signifikansi $5 \%$ dan $d k=80$. Diperoleh harga $t_{\text {hitung }}=4,157>$ harga $t_{\text {tabel }}=2,000$. Hal ini berarti terdapat perbedaan yang signifikan kompetensi pengetahuan IPA kelompok siswa yang dibelajarkan melalui model pembelajaran auditory, intellectualy, repetition berbantuan media audio visual dengan kelompok siswa yang dibelajarkan melalui pembelajaran konvensional di kelas IV SD Gugus Kompyang Sujana Kecamatan Denpasar Utara tahun ajaran 2017/2018. Dengan demikian model pembelajaran auditory, intellectualy, repetition berbantuan media audio visual berpengaruh terhadap kompetensi pengetahuan IPA siswa kelas IV SD Gugus Kompyang Sujana Kecamatan Denpasar Utara tahun ajaran 2017/2018.
\end{abstract}

Kata kunci: auditory intellectualy repetition, audio visual, kompetensi pengetahuan IPA

\begin{abstract}
This research was aimed at determining the significant differences regarding knowledge competence of science between groups of students applying auditory, intellectualy, repetition learning model using audio visual media with group of students who applied conventional learning in grade IV of SD Gugus Kompyang Sujana in North Denpasar, academic year 2017/2018. The type of research used was quasi experiment by using non-equivalent group design. The population of this study were 346 students covering all the fourth graders of SD Gugus Kompyang Sujana in North Denpasar, academic year 2017/2018. Sampling was done by group sample technique, which was held by doing random in class group, so that the following results were obtained; IVA grade of SD Negeri 4 Tonja as experiment class and IV grade of SD Negeri 4 Peguyangan as control class. The result of calculation of "gain" data score showed the average value of science knowledge competence of experimental class students was higher than the average knowledge competence of science students of control class (experiment $=0,63>$ control $=0,50$ ). Hypothesis testing was analyzed using the t-test with the formula "polled variance". Testing criteria at significance level of $5 \%$ and $\mathrm{dk}=80$. Provided $\mathrm{t}_{\text {count }}$ value $=4,157>t_{\text {table }}$ value $=2,000$ This means that there were significant differences regarding knowledge
\end{abstract}


competence of science in groups of students applying auditory, intellectualy, repetition learning model using audio visual media with group of students who applied conventional learning in grade IV of SD Gugus Kompyang Sujana in North Denpasar, academic year 2017/2018. Thus, auditory, intellectualy, repetition learning model using audio visual media have an effect on science knowledge competence of fourth grader students of SD Gugus Kompyang Sujana in North Denpasar in academic year $2017 / 2018$

Keywords: auditory intellectualy repetition, audio visual, competence knowledge of science

\section{Pendahuluan}

Meningkatkan kualitas sumber daya manusia yang cerdas dalam upaya membangun bangsa sangat dipengaruhi oleh tingkat pendidikan. Pada era globalisasi peningkatan kualitas sumber daya manusia harus menjadi target utama yang direalisasikan. Pendidikan merupakan komponen utama dalam hal meningkatkan kualitas sumber daya manusia. Tenaga pendidik dalam hal ini guru menjadi salah satu pemegang peranan yang tak kalah penting. Di dalam pendidikan akan berlangsung suatu proses yang melibatkan guru dengan siswanya untuk mencapai sasaran dan tujuan. Tingkat keberhasilannya sangat dipengaruhi oleh kurikulum yang ada. Di Indonesia telah beberapa kali terjadi perubahan kurikulum. Perubahan kurikulum tersebut tak terelakan dalam proses perkembangan pendidikan. Kurikulum selalu mengalami penyesuaian dengan perkembangan masyarakat.

Undang-Undang Nomor 20 Tahun 2003 tentang Sistem Pendidikan Nasional menyebutkan "kurikulum adalah seperangkat rencana dan pengaturan mengenai tujuan, isi, dan bahan pelajaran serta cara yang digunakan sebagai pedoman penyelenggaraan kegiatan pembelajaran untuk mencapai tujuan pendidikan tertentu".

Di Indonesia kini sedang berlaku kurikulum 2013. Kriteria kualifikasi kemampuan lulusan mencakup sikap, pengetahuan dan keterampilan. Pembelajaran yang dilaksanakan adalah pembelajaran tematik integratif, pada proses pelaksanaannya memberikan kesempatan kepada siswa untuk mengenal dan memahami suatu tema dengan berbagai mata pelajaran.

Kegiatan pembelajaran dengan pendekatan saintifik di sekolah dasar dirancang sedemikian rupa agar siswa aktif selama proses pembelajaran. Dalam pendekatan saintifik siswa mendapatkan pengalaman belajar melalui kegiatan melakukan pengamatan atau observasi, mengajukan pertanyaan, melakukan percobaan atau memperoleh informasi, mengasosiasikan, dan berkomunikasi. Hal tersebut akan berdampak pada pola pikir siswa karena pengetahuan seseorang terbentuk dengan adanya interaksi serta pengalaman. Proses pembelajaran harus memberikan pengalaman yang baik kepada siswa, mengenai cara belajar, berinteraksi dengan orang lain, mengemukakan ide atau pikiran serta pengalaman-pengalamannya dengan menggunakan pendekatan saintifik.

Keberhasilan suatu pembelajaran adalah pada saat siswa telah mendapatkan pengalaman belajarnya. Keberhasilan siswa dalam belajar tergantung pada dua hal yaitu faktor dari siswa dan faktor dari guru. Salah satu komponen penting yang mempengaruhi tingkat keberhasilan suatu pembelajaran adalah kompetesi.

Kompetensi merupakan perpaduan tingkah laku dan pengetahuan serta nilai-nilai dasar yang dapat direfleksikan dalam kemampuan berpikir dan bertindak siswa sebagai yang dicapai melalui kegiatan mengajar yang bermakna dan penuh arti (Yusuf, 2015). Kompetensi adalah pengetahuan, keterampilan, sikap dan nilai-nilai yang direfleksikan dalam kebiasaan berpikir serta bertindak (Arifin, 2014). Kompetensi merupakan kemampuan penguasaan sikap dan keterampilan tentang suatu mata pelajaran tertentu (Agung, 2011).

Berdasarkan pendapat tersebut dapat disimpulkan bahwa kompetensi merupakan perpaduan pengetahuan, keterampilan, sikap serta nilai-nilai dasar yang dapat diterapkan dalam kebiasaan berpikir dan bertindak siswa untuk tujuan yang akan dicapai melalui kegiatan mengajar yang bermakna dan penuh arti. Kompetensi mencakup tiga ranah atau 
aspek yang dapat dijadikan landasan dalam melaksanakan pembelajaran dan penilian yang meliputi pengetahuan, sikap dan keterampilan.

IPA merupakan usaha manusia dalam memahami alam semesta melalui pengamatan yang tepat pada sasaran, dengan melalui prosedur tertentu serta dijelaskan dengan penalaran sehingga mendapatkan suatu kesimpulan (Susanto, 2013). IPA merupakan rumpun ilmu yang memiliki karakteristik khusus yaitu mempelajari fenomena alam yang faktual, baik berupa kenyataan atau kejadian dan hubungan sebab akibatnya (Wisudawati, 2014). IPA adalah pengetahuan tentang alam semesta berikut dengan segala isinya (Samatowa, 2016).

Berdasarkan pendapat tersebut dapat disimpulkan bahwa IPA merupakan ilmu pengetahuan yang mempelajari tentang alam semesta dan fenomena alam yang faktual, baik berupa kenyataan atau kejadian beserta hubungan sebab akibatnya melalui prosedur tertentu dan dijelaskan dengan penalaran sehingga mendapatkan suatu simpulan.

Kompetensi pengetahuan IPA merupakan perubahan perilaku siswa yang mencerminkan kemampuan siswa terhadap penguasaan muatan materi IPA pada kemampuan berpikir serta dimensi pengetahuan, yang diukur menggunakan skor tes kompetensi pengetahuan setelah mengikuti proses pembelajaran.

Pembelajaran IPA di sekolah dasar dapat memberikan kesempatan untuk memupuk rasa ingin tahu siswa secara alamiah. Sehingga dapat membantu siswa mengembangkan kemampuan bertanya dan mencari jawaban atas permasalahan yang tengah dihadapi.

Berdasarkan hasil observasi pembelajaran dan informasi yang diperoleh dari ketua gugus, kepala sekolah serta guru-guru khususnya guru wali kelas IV SD Gugus Kompyang Sujana Kecamatan Denpasar Utara, terdapat temuan siswa jarang mengajukan pertanyaan atau mengungkapkan pendapatnya pada saat pembelajaran berlangsung. Kegiatan pembelajaran dilakukan hanya terpusat pada penyampaian materi dalam buku teks saja. Keadaan ini mendorong siswa untuk berusaha menghafal pada setiap kali akan diadakan ulangan atau ujian. Sehingga menyebabkan siswa kurang termotivasi dalam mengikuti pembelajaran, sehingga banyak siswa yang belum dapat mencapai kompetensi yang ditetapkan sekolah. Untuk itu diperlukan rancangan pembelajaran yang menarik dan menyenangkan agar siswa termotivasi dalam mengikuti proses pembelajaran.

Keberhasilan suatu proses pembelajaran tidak terlepas dari kemampuan guru mengembangkan model-model pembelajaran yang mengacu pada tingkat keterlibatan siswa secara aktif di dalam proses pembelajaran. Model-model pembelajaran yang dipilih dan dikembangkan oleh guru hendaknya merupakan model pembelajaran yang dapat mendorong siswa untuk belajar dengan mendayagunakan potensi yang miliki secara optimal. Salah satunya adalah model pembelajaran auditory, intellectualy, repetition. Model pembelajaran auditory, intellectualy, repetition merupakan suatu model pembelajaran yang dapat mendorong tumbuhnya rasa senang serta antusias siswa dalam mengikuti pembelajaran, meningkatkan motivasi dalam mengerjakan tugas dan dapat memudahkan siswa memahami materi sehingga memungkinkan siswa memiliki kompetensi pengetahuan yang baik.

Shoimin (2014) menyatakan, model pembelajaran auditory, intellectualy, repetition meliputi tiga aspek, yaitu auditory, intellectualy, dan repetition. Ketiga aspek dalam model pembelajaran auditory, intellectualy, repetition tersebut diintegrasikan sedemikian rupa sehingga siswa dan guru secara bersama-sama dapat menghidupkan suasana kelas menjadi lebih kondusif.

Shoimin (2014) menyatakan kelebihan dari model pembelajaran auditory, intellectualy, repetition, diantaranya (1) siswa menjadi lebih aktif berpartisipasi dalam pembelajaran dan sering mengemukakan idenya, (2) siswa memiliki kesempatan lebih banyak dalam memanfaatkan pengetahuan dan keterampilan, (3) siswa dengan kemampuan rendah dapat merespon permasalahan dengan cara sendiri, (4) siswa termotivasi memberikan bukti atau penjelasan, (5) siswa memiliki banyak pengalaman untuk menemukan sesuatu dalam menjawab permasalahan. Pembelajaran dikemas menjadi lebih variatif sehingga tidak membosankan dan dapat menumbuhkan antusias belajar siswa. Model pembelajaran 
auditory, intellectualy, repetition lebih bermakna dan efektif jika dipadukan dengan media pembelajaran.

Salah satu media inovatif yang dapat dipadukan dengan model pembelajaran auditory, intellectualy, repetition dalam membentuk terjadinya proses pembelajaran yang bermakna adalah media audio visual. Di dalam proses pembelajaran media audio visual merupakan sebuah alat bantu yang dipergunakan dalam pembelajaran untuk membantu tulisan dan kata yang diucapkan dalam menyampaikan materi pembelajaran (Wati, 2016). Adapun jenis media yang tergolong dalam audio visual diantaranya adalah film, video dan televisi. Video dapat diartikan sebagai sesuatu yang berkaitan dengan apa yang dapat dilihat, terutama gambar hidup atau bergerak, proses perekaman dan penayangannya tentunya melibatkan teknologi (Wati, 2016).

Model pembelajaran auditory, intellectualy, repetition berbantuan media audio visual adalah model yang di dalam penerapannya siswa dapat saling berkomunikasi dan kemudian mempraktikkan keterampilan serta membentuk kelompok untuk bersama-sama menyelesaikan masalah. Dengan berpikir dan berkonsentrasi yang juga melatih daya intelektual siswa dan membiasakan siswa untuk mengingat serta memahami benar materi pembelajaran dengan cara repetisi agar tidak mudah dilupakan tentunya dengan penggunaan media audio visual. Setiap siswa dapat memperoleh pengetahuan yang sama, sehingga pembelajaran menjadi efektif dan efisien.

Tujuan penelitian ini adalah untuk mengetahui perbedaan yang signifikan kompetensi pengetahuan IPA antara kelompok siswa yang dibelajarkan melalui model pembelajaran auditory, intellectualy, repetition berbantuan media audio visual dengan kelompok siswa yang dibelajarkan melalui pembelajaran konvensional di kelas IV SD Gugus Kompyang Sujana Kecamatan Denpasar Utara tahun ajaran 2017/2018.

\section{Metode}

Penelitian menggunakan rancangan eksperimen kuasi dengan desain rancangan kelompok non-ekuivalen.

\begin{tabular}{|llll|}
\hline $\mathrm{O} 1$ & $\mathrm{X}$ & $\mathrm{O} 2$ & (eksperimen) \\
$\mathrm{O} 3$ & - & $\mathrm{O} 4$ & (kontrol) \\
\hline
\end{tabular}

Gambar 1. Rancangan Kelompok Non-ekuivalen, pretest kelas eksperimen (O1), posttest kelas eksperimen (O2), pretest kelas kontrol (O3), posttest kelas kontrol (O4), perlakuan pada kelas eksperimen $(\mathrm{X})$

Pelaksanaan penelitian terdiri dari tiga tahapan yaitu, tahap persiapan, tahap pelaksanaan dan tahap akhir eksperimen. Pada tahap persiapan eksperimen, kegiatan yang dilaksanakan adalah yang pertama, pengumpulan informasi pada masing-masing SD di Gugus Kompyang Sujana Kecamatan Denpasar Utara untuk mengetahui jumlah siswa. Kedua, mempersiapkan pembelajaran sesuai dengan kurikulum yang digunakan dan berdiskusi bersama wali kelas terkait dengan materi yang akan diujicobakan. Ketiga, mengkonsultasikan RPP (Rencana Pelaksanaan Pembelajaran) beserta video pembelajaran yang digunakan dengan dosen pembimbing juga dilaksanakan pada tahap ini. Keempat, mengadakan uji coba instrumen penelitian yang akan digunakan sebagai soal pretest dan posttest. Kelima, memberikan pretest kepada kedua kelas yang telah diundi untuk pengumpulan data pengetahuan awal siswa. Selain itu dilakukan juga uji kesetaraan sampel dengan menggunakan data pretest. Kemudian melakukan pengundian unuk menentukan kelas eksperimen dan kelas kontrol.

Saat pelaksanaan eksperimen kegiatan yang dilakukan adalah memberikan perlakuan pada kelas eksperimen berupa model pembelajaran auditory, intellectualy, repetition berbantuan media audio visual sebanyak 6 kali pertemuan. 
Pada tahap akhir eksperimen, kegiatan yang dilakukan adalah pemberian posttest kepada kelas eksperimen dan kelas kontrol.

Populasi dari penelitian adalah seluruh siswa kelas IV SD Gugus Kompyang Sujana Kecamatan Denpasar Utara tahun ajaran 2017/2018, yang terdiri dari 10 kelas dalam 7 sekolah dasar. Sampel ditentukan dengan teknik sampling. Teknik sampling yang digunakan pada saat pengambilan sampel adalah teknik sampel kelompok. Teknik sampel kelompok dapat digunakan apabila sampel yang tersedia berupa unit-unit atau rumpun di dalam populasi (Setyosari, 2015). Sampel yang diambil berupa kelompok kelas yang telah terbentuk sebelumnya yang disebabkan karena tidak memungkinkan mengambil secara acak setiap individual anak dari masing-masing kelas yang ada. Dengan demikian maka semua anggota populasi memiliki kesempatan yang sama untuk dipilih menjadi sampel penelitian.

Penentuan sampel yang menjadi kelas eksperimen dan kelas kontrol dilakukan dengan cara pengundian. Cara undian dilakukan dengan menuliskan semua nama kelas IV yang ada di Gugus Kompyang Sujana Kecamatan Denpasar Utara pada kertas kecil yang kemudian digulung dan semua dimasukan ke dalam suatu wadah. Keluarkan satu gulungan kertas dari dalam wadah secara acak. Kemudian keluarkan satu lagi gulungan kertas dari dalam wadah secara acak tanpa mengikut sertakan gulungan pertama yang telah keluar sebelumnya. Setelah mendapatkan dua kelas dari setiap kelas IV pada 7 sekolah maka kedua kelompok tersebut diuji kesetaraannya dengan data pretest dari kedua kelas tersebut. Teknik yang digunakan dalam menguji kesetaraan kedua kelas tersebut adalah uji-t. Kedua kelas yang telah dinyatakan setara maka dilanjutkan dengan menentukan kelas eksperimen dan kelas kontrol. Sehingga diperoleh kelas IVA SD Negeri 4 Tonja sebagai kelas eksperimen dan kelas IV SD Negeri 4 Peguyangan sebagai kelas kontrol.

Data yang dikumpulkan dalam penelitian adalah data kompetensi pengetahuan IPA siswa kelas IV SD Gugus Kompyang Sujana Kecamata Denpasar Utara tahun ajaran 2017/2018. Metode pengumpulan data yang digunakan dalam penelitian adalah metode tes. Jenis tes yang digunakan adalah tes objektif dalam bentuk pilihan ganda biasa yang disusun berdasarkan indikator-indikator muatan materi IPA, dengan empat pilihan jawaban, yaitu a, $\mathrm{b}, \mathrm{c}$, atau $\mathrm{d}$. Tes pilihan ganda terdiri atas keterangan tentang suatu pengertian yang belum lengkap serta satu kemungkinan jawaban benar sesuai dengan kunci jawaban dan beberapa pilihan jawaban pengecoh (Arikunto, 2015). Data yang digunakan untuk melakukan analisis data gain skor yang dinormalisasi dari hasil pretest dan hasil posttest yang telah didapatkan.

Analisis statistik deskriptif merupakan suatu cara pengolahan data yang dilakukan dengan jalan menerapkan rumus-rumus statistik deskriptif untuk menggambarkan suatu objek atau variabel tertentu sehingga diperoleh kesimpulan umum (Agung, 2014). Data dianalisis dengan analisis statistik deskriptif dan inferensial. Data yang disajikan dalam statistik deskriptif adalah perhitungan rata-rata (mean), standar deviasi dan varians yang kemudian dikonversikan ke dalam PAN skala lima.

Analisis statistik inferensial merupakan suatu cara pengolahan data yang dilaksanakan dengan jalan menerapkan rumus-rumus statistik inferensial yang digunakan untuk menguji hipotesis penelitian (Agung 2014). Teknik analisis data yang digunakan adalah uji hipotesis dengan menggunakan uji-t. Sebelum uji-t dapat dilakukan, terlebih dahulu dilaksanakan uji prasyarat analisis dengan uji normalitas sebaran data dan uji homogenitas varians.

Pada penelitian ini untuk menghitung uji normalitas sebaran data digunakan rumus Kolmogorov-Smirnov dengan kriteria pengujian pada taraf signifikasi $5 \%$, jika harga nilai maksimum $\left|\mathrm{F}_{\mathrm{T}}-\mathrm{F}_{\mathrm{S}}\right|<$ harga nilai tabel Kolmogorov-Smirnov, maka $\mathrm{H}_{0}$ diterima dan data berdistribusi normal. Sedangkan jika harga nilai maksimum $\left|F_{T}-F_{S}\right|>$ harga nilai tabel Kolmogorov-Smirnov, maka $\mathrm{H}_{0}$ ditolak dan data tidak berdistribusi normal. Uji homogenitas varians dilakukan menggunakan uji $\mathrm{F}$ dengan kriteria pengujian pada taraf signifikansi $5 \%$ dengan derajat kebebasan untuk pembilang $n_{1}-1$ dan derajat kebebasan untuk penyebut $n_{2^{-}}$ 1. Jika harga $F_{\text {hitung }} \leq F_{\text {tabel }}$, maka sampel dinyatakan homogen, sedangkan jika harga $F_{\text {hitung }}>$ $F_{\text {tabel, }}$ maka sampel dinyatakan tidak homogen.

Pengujian hipotesis terhadap hiotesis observasi $\left(\mathrm{H}_{0}\right)$ dianalisis menggunakan uji-t dengan rumus polled varians, dengan kriteria pengujian pada taraf signifikansi $5 \%$ dan 
derajat kebebasan $(d k)=n_{1}+n_{2}-2$. Jika $t_{\text {hitung }} \leq t_{\text {tabel }}$, maka $H_{0}$ diterima, sedangkan jika $t_{\text {hitung }}$ $>t_{\text {tabel}}$, maka $\mathrm{H}_{0}$ yang ditolak.

\section{Hasil dan Pembahasan}

Hasil penelitian disajikan dalam bentuk deskripsi data kompetensi pengetahuan IPA tema daerah tempat tinggalku pada siswa kelas IV SD Gugus Kompyang Sujana Kecamatan Denpasar Utara tahun ajaran 2017/2018. Deskripsi data hasil penelitian memaparkan mengenai nilai rata-rata, standar deviasi, varians, nilai maksimum dan nilai minimum dari data gain skor ternormalisasi kompetensi pengetahuan IPA pada kelompok siswa yang dibelajarkan melalui model pembelajaran auditory, intellectualy, repetition berbantuan media audio visual dan kelompok siswa yang dibelajarkan secara konvensional.

Hasil analisis data kompetensi pengetahuan IPA kelompok siswa yang dibelajarkan melalui model pembelajaran auditory, intellectualy, repetition berbantuan media audio visual di kelas IV SD Gugus Kompyang Sujana Kecamatan Denpasar Utara tahun ajaran 2017/2018, menunjukkan nilai rata-rata $=0,63$ dengan standar deviasi $=0,14$ dan varians $=$ 0,020 . Selain itu nilai maksimum pada kelompok eksperimen adalah 0,9 dan nilai minimun adalah 0,4. Dikonversikan pada tabel PAN skala lima, sehingga dapat diketahui kompetensi pengetahuan IPA siswa kelas eksperimen berada pada kategori cukup (C).

Hasil analisis data kompetensi pengetahuan IPA kelompok siswa yang dibelajarkan melalui pembelajaran konvensional di kelas IV SD Gugus Kompyang Sujana Kecamatan Denpasar Utara tahun ajaran 2017/2018, diperoleh nilai rata-rata $=0,50$ dengan standar deviasi $=0,14$ dan varians $=0,020$. Selain itu nilai maksimum pada kelompok eksperimen adalah 0,8 dan nilai minimun adalah 0,2. Dikonversikan pada tabel PAN skala lima, sehingga dapat diketahui kompetensi pengetahuan IPA siswa kelas kontrol berada pada katagori cukup (C).

Berdasarkan hasil perhitungan analisis deskripsi data kompetensi pengetahuan IPA menunjukkan bahwa kompetensi pengetahuan IPA kelas eksperimen, yaitu kelompok siswa yang dibelajarkan dengan menggunakan model pembelajaran auditory, intellectualy, repetition berbantuan media audio visual memiliki nilai rata-rata lebih tinggi daripada kelas kontrol, yaitu kelompok siswa yang dibelajarkan secara konvensional.

Sebelum melakukan uji hipotesis terlebih dahulu dilakukan uji prasyarat analisis. Uji prasyarat analisis meliputi uji normalitas sebaran data dan uji homogenitas varians.

Hasil uji normalitas sebaran data kelas eksperimen, menunjukan harga nilai maksimum $\left|F_{T}-F_{S}\right|$ sebagai angka penguji normalitas, yaitu 0,110 . Harga tersebut kemudian dibandingkan dengan harga nilai tabel Kolmogorov-Smirnov untuk taraf signifikansi $5 \%(\alpha=$ 0,05 ) dan $N=43$, sehingga diperoleh harga nilai tabel Kolmogorov-Smirnov, yaitu 0,207. Oleh karena Harga nilai maksimum $\left|\mathrm{F}_{\mathrm{T}}-\mathrm{F}_{\mathrm{S}}\right|=0,110<$ harga nilai tabel Kolmogorov-Smirnov $=0,207$, maka $\mathrm{H}_{0}$ diterima dan sebaran data gain skor ternormalisasi kompetensi pengetahuan IPA kelas eksperimen berdistribusi normal.

Hasil uji normalitas sebaran data kelas kontrol, menunjukan harga nilai maksimum $\mid F_{T}$ $F_{S} \mid$ sebagai angka penguji normalitas, yaitu 0,146. Harga tersebut kemudian dibandingkan dengan harga nilai tabel Kolmogorov-Smirnov untuk taraf signifikansi $5 \%(\alpha=0,05)$ dan $N=$ 39 , sehingga diperoleh harga nilai tabel Kolmogorov-Smirnov, yaitu 0,213. Oleh karena Harga nilai maksimum $\left|F_{T}-F_{S}\right|=0,146<$ harga nilai tabel Kolmogorov-Smirnov $=0,213$, maka $\mathrm{H}_{0}$ diterima dan sebaran data gain skor ternormalisas kompetensi pengetahuan IPA kelas kontrol berdistribusi normal.

Hasil perhitungan menunjukan harga $F_{\text {hitung }}=1,00$, harga ini kemudian dibandingkan dengan harga $F_{\text {tabel }}$ pada taraf signifikansi $5 \%(\alpha=0,05)$ dengan dk untuk pembilang $(43-1$ $=42)$ dan dk untuk penyebut $(39-1=38)$, sehingga diperoleh harga $F_{\text {tabel }}=1,71$. Oleh karena harga $F_{\text {hitung }}=1,00<$ harga $F_{\text {tabel }}=1,71$, maka $H_{0}$ diterima dan data gain skor ternormalisas kompetensi pengetahuan IPA sampel penelitian dinyatakan memiliki varians yang homogen.

Berdasarkan hasil uji prasyarat analisis yang meliputi uji normalitas sebaran data dan uji homogenitas varians, disimpulkan bahwa data kedua kelompok sampel penelitian ialah 
berdistribusi normal dan memiliki varians yang homogen. Dengan demikian, uji hipotesis menggunakan uji-t rumus polled varians dapat dilakukan. Berdasarkan hasil uji hipotesis yang telah dilakukan dengan data gain skor ternormalisasi diperoleh hasil yang disajikan pada tabel 1.

Tabel 1

Hasil uji-t Kompetensi Pngetahuan IPA Sampel Penelitian

\begin{tabular}{cccccccc}
\hline No & Sampel & $\mathbf{N}$ & $\overline{\mathbf{x}}$ & $\mathbf{S}^{2}$ & $\mathbf{t}_{\text {hitung }}$ & $\mathbf{t}_{\text {tabel }}$ & Simpulan \\
\hline 1 & $\begin{array}{c}\text { Kelas } \\
\text { Eksperimen }\end{array}$ & 43 & 0,63 & 0,020 & & & \\
2 & Kelas Kontrol & 39 & 0,50 & 0,020 & & & $H_{0}$ ditolak \\
\hline
\end{tabular}

Hasil analisis menunjukan harga $t_{\text {hitung }}=4,157$, harga ini kemudian dibandingkan dengan harga $t_{\text {tabel }}$ pada taraf signifikansi $5 \%(\alpha=0,05)$ dengan dk $(43+39-2=80)$, sehingga diperoleh harga $t_{\text {tabel }}=2,000$. Oleh karena harga $t_{\text {hitung }}=4,157>$ harga $t_{\text {tabel }}=2,000$, maka $\mathrm{H}_{0}$ ditolak. Hal ini berarti terdapat perbedaan yang signifikan kompetensi pengetahuan IPA kelompok siswa yang dibelajarkan melalui model pembelajaran auditory, intellectualy, repetition berbantuan media audio visual dengan kelompok siswa yang dibelajarkan melalui pembelajaran konvensional di kelas IV SD Gugus Kompyang Sujana Kecamatan Denpasar Utara tahun ajaran 2017/2018. Dengan demikian model pembelajaran auditory, intellectualy, repetition berbantuan media audio visual berpengaruh terhadap kompetensi pengetahuan IPA siswa kelas IV SD Gugus Kompyang Sujana Kecamatan Denpasar Utara tahun ajaran 2017/2018.

Berdasarkan perolehan nilai kompetensi pengetahuan IPA siswa pada kedua kelompok dapat diketahui bahwa kedua kelompok yang awalnya memiliki kemampuan setara. Setelah diberikan perlakuan pada kelas eksperimen, perolehan nilai kompetensi pengetahuan IPA mengalami perbedaan. Kompetensi pengetahuan IPA siswa pada kelas eksperimen lebih baik apabila dibandingkan dengan kompetensi pengetahuan IPA siswa pada kelas kontrol. Perbedaan hasil kompetensi pengetahuan pada kelas eksperimen dibandingkan kelas kontrol disebabkan oleh perlakuan, yaitu berupa model pembelajaran auditory, intellectualy, repetition berbantuan media audio visual yang diberikan kepada kelas ekperimen.

Pada kegiatan pembelajaran di kelas eksperimen menggunakan model pembelajaran auditory, intellectualy, repetition berbantuan media audio visual, berjalan dengan optimal dan kondusif. Disebabkan oleh karena model pembelajaran auditory, intellectualy, repetition berbantuan media audio visual merupakan suatu model pembelajaran yang dapat mendorong tumbuhnya rasa senang serta antusias siswa dalam mengikuti pembelajaran, meningkatkan motivasi dalam mengerjakan tugas dan dapat memudahkan siswa memahami materi dengan media audio visual.

Langkah-langkah pada model pembelajaran auditory, intellectualy, repetition berbantuan media audio visual membuat siswa lebih aktif karena dikemas dengan kegiatan pembelajaran yang membuat siswa saling berkomunikasi dan kemudian mempraktikkan keterampilan serta membentuk kelompok untuk bersama-sama menyelesaikan masalah. Berpikir dan berkonsentrasi dapat melatih daya intelektual siswa dan membiasakan siswa untuk mengingat serta memahami benar materi pembelajaran dengan cara repetisi agar tidak mudah dilupakan tentunya dengan penggunaan media audio visual. Setiap siswa memperoleh pengetahuan yang sama, sehingga pembelajaran menjadi efektif dan efisien. Hal tersebut didukung oleh Sohimin (2014) yang menyatakan kelebihan dari model pembelajaran auditory, intellectualy, repetition, diantaranya (1) siswa menjadi lebih aktif berpartisipasi dalam 
pembelajaran dan sering mengemukakan idenya, (2) siswa memiliki kesempatan lebih banyak dalam memanfaatkan pengetahuan dan keterampilan, (3) siswa dengan kemampuan rendah dapat merespon permasalahan dengan cara sendiri, (4) siswa termotivasi memberikan bukti atau penjelasan, (5) siswa memiliki banyak pengalaman untuk menemukan sesuatu dalam menjawab permasalahan.

Pembelajaran dengan menggunakan model pembelajaran auditory, intellectualy, repetition berbantuan media audio visual khususnya pada muatan materi IPA tema daerah tempat tinggalku memberikan kesempatan yang lebih luas kepada siswa untuk mengonstrusikan pengetahuannya melalui berbagai kegiatan bermakna dan teratur yang tentunya mengembirakan bagi siswa pada setiap langkah pembelajarannya.

Dengan demikian, pembelajaran menggunakan model pembelajaran auditory, intellectualy, repetition berbantuan media audio visual memiliki keunggulan, yakni dapat membuat pengetahuan yang diperoleh siswa bukan hanya hafalan saja tetapi pengetahuan yang bermakna, sehingga siswa dapat lebih memahami dan tidak cepat melupakan materi yang dipelajari. Model pembelajaran auditory, intellectualy, repetition berbantuan media audio visual memberikan banyak dampak positif terutama pada kompetensi pengetahuan.

Hasil temuan penelitian pada penelitian ini memiliki persamaan dengan penelitian yang relevan sebelumnya dan memperkuat hasil penelitian yang diperoleh. Didukung oleh hasil penelitian Widiastuti (2014) yang menyimpulkan bahwa terdapat pengaruh dari model auditory, intellectualy, repetition (AIR) berbantuan tape recorder terhadap keterampilan berbicara Bahasa Indonesia siswa kelas VI SD Gugus 1 Kuta Utara tahun ajaran 2013/2014. Begitupula dengan hasil penelitian Mahardika (2017) menyimpulkan bahwa model pembelajaran TANDUR berbantuan media audio visual berpengaruh terhadap kompetensi pengetahuan IPA siswa kelas V SD Gugus Srikandi tahun ajaran 2016/2017.

\section{Simpulan dan Saran}

Simpulan hasil penelitian yang telah dipaparkan, yakni hasil analisis data kompetensi pengetahuan IPA kelompok siswa yang dibelajarkan melalui model pembelajaran auditory, intellectualy, repetition berbantuan media audio visual di kelas IV SD Gugus Kompyang Sujana Kecamatan Denpasar Utara tahun ajaran 2017/2018, menunjukan nilai rata-rata $=0,63$ dengan standar deviasi $=0,14$ dan varians $=0,020$. Selain itu nilai maksimum pada kelompok eksperimen adalah 0,9 dan nilai minimun adalah 0,4 . Dikonversikan pada tabel PAN skala lima, sehingga dapat diketahui kompetensi pengetahuan IPA siswa kelas eksperimen berada pada katagori cukup (C).

Hasil analisis data kompetensi pengetahuan IPA kelompok siswa yang dibelajarkan melalui pembelajaran konvensional di kelas IV SD Gugus Kompyang Sujana Kecamatan Denpasar Utara tahun ajaran 2017/2018, menunjukan nilai ratarata $=0,50$ dengan standar deviasi $=0,14$ dan varians $=0,020$. Selain itu nilai maksimum pada kelompok eksperimen adalah 0,8 dan nilai minimun adalah 0,2. Dikonversikan pada tabel PAN skala lima, sehingga dapat diketahui kompetensi pengetahuan IPA siswa kelas kontrol berada pada katagori cukup (C).

Hasil analisis uji-t kompetensi pengetahuan ipa kelompok siswa yang dibelajarkan melalui model pembelajaran auditory, intellectualy, repetition berbantuan media audio visual dengan kelompok siswa yang dibelajarkan melalui pembelajaran konvensional di kelas IV SD Gugus Kompyang Sujana Kecamatan 
Denpasar Utara tahun ajaran 2017/2018, menunjukan harga $t_{\text {hitung }}=4,157>$ harga $t_{\text {tabel }}=2,000$, maka $\mathrm{H}_{0}$ ditolak. Hal ini berarti terdapat perbedaan yang signifikan kompetensi pengetahuan IPA kelompok siswa yang dibelajarkan melalui model pembelajaran auditory, intellectualy, repetition berbantuan media audio visual dengan kelompok siswa yang dibelajarkan melalui pembelajaran konvensional di kelas IV SD Gugus Kompyang Sujana Kecamatan Denpasar Utara tahun ajaran 2017/2018.

Berdasarkan pemaparan tersebut dapat disimpulkan bahwa model pembelajaran auditory, intellectualy, repetition berbantuan media audio visual berpengaruh terhadap kompetensi pengetahuan IPA siswa kelas IV SD Gugus Kompyang Sujana tahun ajaran 2017/2018.

Saran yang dapat diajukan, yakni kepada guru, melihat hasil kompetensi pengetahuan pada muatan materi IPA dengan penerapan model pembelajaran auditory, intellectualy, repetition berbantuan media audio visual hendaknya guru menerapkan model pembelajaran ini khususnya pada muatan materi IPA.

Kepada peneliti lain, dapat melakukan penelitian lebih lanjut mengenai pengaruh model pembelajaran auditory, intellectualy, repetition berbantuan media audio visual pada muatan materi pembelajaran yang berbeda dan pada sampel yang berbeda sehingga hasil penelitian ini benar-benar dapat menggambarkan keadaan sesungguhnya yang terjadi di lapangan.

Kepada lembaga pendidikan, hendaknya menyediakan sarana yang maksimal untuk menunjang pembelajaran agar siswa semakin termotivasi untuk belajar dan memanfaatkan sarana tersebut untuk mengoptimalkan komptensi $\mathrm{p}$ engetahuan siswa, sehingga mutu sekolah menjadi semakin meningkat.

\section{Daftar Pustaka}

Agung, A. A. G. 2011. Pengantar Evaluasi Pendidikan. Singaraja: Jurusan Teknologi Pendidikan, Fakultas Ilmu Pendidikan Universitas Pendidikan Ganesha.

Agung, A. A. G. 2014. Buku Ajar Metodologi Penelitian Pendidikan. Yogyakarta: Aditya Media Publishing.

Arikunto, Suharsimi. 2015. Dasar-Dasar Evaluasi Pendidikan. Jakarta: PT. Bumi Aksara.

Kurniasih, Imas dan Berlin Sani. 2014. Sukses Mengimplementasikan Kurikulum 2013 Memahami Berbagai Aspek Dalam Kurikulum 2013. Yogyakarta: Kata Pena.

Mahardika, I.G. Putu Putra. (2017). “Pengaruh Model Pembelajaran 'TANDUR' Berbantuan Media Audio Visual terhadap Kompetensi Pengetahuan IPA Siswa Kelas V". Jurusan PGSD Universitas Pendidikan Ganesha Singaraja, Indonesia, Volume 5, Nomor 2 (hlm.1-9). Tersedia pada https://ejournal.undiksha.ac.id/index.php/JJPGSD/article/view/10909 (diakses tanggal 11 Januari 2018).

Samatowa, Usman. 2016. Pembelajaran IPA di Sekolah Dasar. Jakarta: PT. Indeks.

Setyosari, Punaji. 2015. Metode Penelitian Pendidikan dan Pengembangan. Jakarta: Prenadamedia group.

Shoimin, Aris. 2014. 68 Model Pembelajaran Inovatif dalam Kurikulum 2013. Yogyakarta: Ar-ruzz Media.

Susanto, Ahmad. 2013. Teori Belajar dan pembelajaran di Sekolah Dasar. Jakarta:

Undang-Undang Republik Indonesia Nomor 20 Tahun 2003 tentang Sistem Pendidikan Nasional. 2003. Jakarta: Pemerintah Republik Indonesia. Prenadamedia Group.

Wati, Ega Rima. 2016. Ragam Media Pembelajaran Visual-Audio Visual- Komputer-Power Point- Internet-Interactive Video. Yogyakarta: Kata Pena

Widiastuti, A.A.Pt Yuni. (2014). "Pengaruh Model Auditory Intellectualy Repetition Berbantuan terhadap Keterampilan Berbicara". Jurusan Pendidikan Guru Sekolah Dasar FIP Universitas Pendidikan Ganesha Singaraja Indonesia, Volume 2, Nomor 1 
(hlm.---). Tersedia pada https:// ejournal.undiksha.ac.id/index.php/JJPGSD/article/view/2223 (diakses tanggal 11 Nopember 2017)

Wisudawati, Asih Widi dan Eka Sulistyowati. 2014. Metodologi Pembelajaran IPA. Jakarta: PT. Bumi Aksara.

Yusuf, Muri. A. 2015. Asesmen dan Evaluasi Pendidikan Pilar Penyedia Informasi dan Kegiatan pengendalian Mutu Pendidikan. Jakarta: Prenadamedia Group. 